\title{
The approach to sexuality in PNLD textbooks: a focus on STI/AIDS and condoms
}

\section{Abordagem da sexualidade nos livros didático do PNLD: foco nas IST/AIDS e preservativos}

\author{
Célia de Souza Ladislau Filha ${ }^{1}$. Gabriel Ribeiro ${ }^{1}$
}

\begin{abstract}
The patent contents in textbooks are selected according to the scientific knowledge (K), values $(\mathrm{V})$ and social practice $(\mathrm{P})$. These three variables are the elements of the educational model, KVP, developed by Clément. The aim of this study was to analyze the Sexual Education approach on textbooks, relating to STD/AIDS and condoms in $158^{\text {th }}$ grade Science textbooks, distributed in Brazil by PNLD in 2014. The data were collected based on two analytical matrices constructed within the European BioheadCitizen Project and analyzed using the KVP model. The results show that despite the small improvement in the type of image present in textbooks, human bodies are still presented in a sectional shape and the images found are not very enlightening regarding sexual intercourse. As for the educational style textual content, only two books were classified in informative and participative category, aspect that indicates limitations on the openness to dialogue about sexuality in most of the analyzed books.
\end{abstract}

Keywords: Sexual education. Textbook. PNLD. KVP model.

Resumo: Os conteúdos patentes nos Livros Didáticos são selecionados de acordo com o Conhecimento cientifico (K), Valores (V) e Prática social (P). Estas três variáveis são elementos constituintes do modelo didático, KVP, desenvolvido por Clément. O objetivo deste estudo foi analisar a abordagem da Educação Sexual nos Livros Didáticos distribuídos no Brasil pelo Programa Nacional do Livro Didático de 2014. Os dados foram recolhidos com base em duas matrizes analíticas construídas no seio do projeto Europeu Biohead-Citizen e analisados utilizando o modelo KVP. Os resultados evidenciaram que apesar do pequeno avanço quanto ao tipo de imagem presente nos Livros Didáticos, os corpos humanos ainda são apresentados de forma seccionada e as imagens encontradas são pouco esclarecedoras no que tange o intercurso sexual. Quanto ao estilo educacional do conteúdo textual, apenas dois livros foram classificados na categoria informativo e participativo, aspecto que indica limitações à abertura ao diálogo sobre sexualidade, na maioria dos livros analisados.

Palavras-chave: Educação sexual. Livro didático. PNLD. Modelo KVP.

\footnotetext{
1 Universidade Federal do Recôncavo da Bahia (UFRB), Centro de Ciências Agrárias, Ambientais e Biológicas, Cruz das Almas, BA, Brasil. E-mail: <celia.ladislau@gmail.com>.
} 


\section{Introduction}

Sexually Transmitted Diseases (STD) or Sexually Transmitted Infections (STI) - nomenclature currently recommended by the World Health Organization (WHO) - is public health problems and worldwide epidemics. World Health Organization (2014) points out that "every day more than one million people contract a STI and it is estimated that each year, 500 million people acquire one of the four STIs: chlamydia, gonorrhea, syphilis, and trichomoniasis."

The acquired immunodeficiency syndrome (AIDS), caused by Human Immunodeficiency Virus (HIV), it is a world epidemic STI. World Health Organization (2014) points that "with more than 36 million of deaths the HIV continues to be a big problem of public health". According to World Health Organization (2014) "in 2012, for about 35.3 millions of people had HIV". The Brazilian Ministry of Health in their epidemiological bulletin (BRASIL, 2013) highlighted that in 2012, 39.185 AIDS cases were reported in Brazil. The Brazilian Department of STD, AIDS and Viral Hepatitis (BRASIL, 2014b), from Health Ministry, estimates that 718.000 people lives with HIV/AIDS in Brazil. Besides, this department estimates that each year, there are reports of 640900 of genital herpes, 685400 of HPV, 937000 of syphilis, 1.5418 million of gonorrhea and 1.9672 million of chlamydia.

One of the ways found to reduce the alarming number of STI cases is the Sexual Education (SE). According to Berger et al. (2008, p. 2), “[...] it is widely accepted that young people have a right to sex education, partly because it is a means by which they are helped to protect themselves against abuse, exploitation, unintended pregnancies and sexually transmitted diseases and HIV/AIDS".

Because of the importance of SE, mainly at the schooling phase, Bernard et al. (2008) conducted an investigation on this topic in different science TBs in countries through Europe, North Africa, Sub-Saharan Africa and the Middle East, focusing on the STI and condom content. The authors of this study used two analytical matrices to identify the educational style in textual content (Cautious, Indicative, Participative and Informative or just Informative) and the presentation of male, female condoms and STIs. To this end, they used the KVP model (the variable $K$ represents scientific knowledge, $V$ values and $P$ practice) to analyze the concepts expressed in TBs, resulting from interactions between the three variables. At the end of the analysis, Bernard et al. (2008) concluded that scientific knowledge inserted in the TB, regarding $\mathrm{SE}$, it is influenced by moral and social values from the developers of these curriculum devices.

Because of the alarming epidemiological data regarding to STI / AIDS in Brazil and the importance of sexual education, it is important to assess the curricular devices (TB) that approach these issues to recognize the values, practices and scientific knowledge that are guiding the educational process, specifically the science education. In order to contribute to this agenda, an analysis of the content on condoms and STI/AIDS is appropriate for its transformer and guiding role exercised by these on the curriculum. These initiatives will help future elaborations of TBs, or even their selection by educators. Moreover, the PNLD calling notice (BRASIL, 2014a) highlighted that should be excluded from PNLD 2014 the TBs that had stereotype or prejudice of sexual orientation or any other kind of discrimination. And more, the TBs should approach gender, non-violence against women, and others aspects to build a fair society (BRASIL, 2014b). Based on the aspects referred, the purpose of this study was to analyze how the approach of Sexual Education in TB takes place in relation to STI / AIDS and condoms, the 
15 most distributed 8th grade Science TBs according to Programa Nacional do Livro Didático (PNLD) of 2014.

\section{Educational system and the values-practice-knowledge triad}

The analytical matrices developed by Bernard et al. (2008) and used in this research were based on the analysis model (KVP), proposed by Clément (2006). This model, which examines the influence of scientific knowledge, values and practices on educational activities built around the concept of didactic transposition, developed by Yves Chevallard. Chevallard (1998) describes a content that has been chosen for the education undergoes a series of transformations that make it suitable for teaching and learning activities. The knowledge transformation to be taught in a knowledge taught is called didactic transposition.

According to Chevallard (1998) the teaching system, represented by the triad teacher, student and knowledge, it is enveloped by the education system, which has structural devices that allow the didactic function, in addition, this system (Learning System) is also subsumed by another level called the noosphere - the society set up by parents, academics, politicians and etc. In the noosphere, all decisions, conflicts, negotiations etc take place, in other words, it is the place where the educational system representatives meet directly and indirectly with the society representatives. "[...] The noosphere is the operational center of the transposition process, [...]. That is the place where every conflict between system and environment is produced and it is a privileged expression place" (CHEVALLARD, 1998, p. 11, our translation).

Chevallard suggested three steps that summarize the didactic transposition process: Scientific knowledge $\rightarrow$ Knowledge to be taught $\rightarrow$ Knowledge taught (CLÉMENT, 2006). While Chevallard (1998) highlighted the scientific knowledge or knowing, as the reference in the didactic transposition, Clément (2006) in his proposal inserted social values and practices. This author points out that the curriculum and teaching programs are not written directly from original scientific articles, but, like the teachers, the TBs authors take into consideration other scientific treaties and different levels of Science popularization such as the Internet, television and science magazines. According to Clément (2006), Chevallard does not take into consideration, in his scheme, the views of the different actors that are part of the education system, which is extremely important to analyze the opinions of many actors in the process of didactic transposition.

Thus, Clément (2006) proposed that interactions between scientific knowledge, values and social practices happens in all instances that are part of the educational system because of the following conclusion: what is taught in school by teachers, as well as what is learned in school by students is directly related to values and social practices. For this author, the didactic transposition edited by Chevallard (1998) did not give space to the conception analysis of the educational system's actors, only mentioned scientific knowledge, knowledge to be taught and the knowledge taught. Therefore, Clément (2006) proposed the KVP model for conception analysis.

The main object of the KVP model built by Clément (2006) is to identify the factors that influence the educational system's actors views over the education system. The letter $K$ represents the scientific knowledge, while the letter $V$ refers to the system of values, finally, the 
letter P, represents the social practices. Clément (2006, p. 9) mentions that in the KVP model, "[...] the concepts are analyzed as interactions between the three poles". Still, according to the author, the KVP model was built "[...] to analyze not only the conceptions of learners (pupils, students,) but also the views of researchers, teachers, and other stakeholders in the education system" (CLÉMENT, 2006, p. 13).

Carvalho (2009, p. 47) defines that, “[...] the pole $\mathrm{K}$, representing scientific knowledge, refers to information from the scientific community, but also the knowledge that each one has, whether near or far from scientific knowledge". Clément (2006, p. 13-14) signals that,

[...] values are attributed to the broad sense: opinions, beliefs, ideologies, $[\ldots]$ while the social practices analyze professional practices of researchers $[\ldots .$.$] , teachers [\ldots]$ students $[. .$.$] ; future student's professional practices when$ they are involved in training; current and future citizenship practices.

Since it was structured, the KVP model has been used by some researchers to analyze different topics addressed by science education (ARAÚJO et al., 2009; CARAVITA et al., 2008; GUIMARÃES et al., 2008) including questions related to sexuality (NUNES et al., 2011), the subject of this investigation.

Nunes et al. (2011) analyzed using the KVP model if the scientific knowledge learned in school and the individuals 'conceptions are sufficient to prevent infection by the HIV virus. This survey showed that most of the students know how the transmission occurs, however, when analyzing the relation between the issues applied in the study - one related to the knowledge about the transmission and the other to the attitude displayed against a HIV virus carrier - the authors concluded that it is not possible to relate scientific knowledge $(\mathrm{K})$ on this issue, with social practices $(\mathrm{P})$, it is possible that the values $(\mathrm{V})$ have greater weight in making a decision.

Taking into consideration the aspects mentioned and the KVP model legitimacy, this research will use this perspective to analyze how the interactions between scientific knowledge, social practices and values are inserted in the TB, focusing on the contents related to STI / AIDS and condoms.

\section{Methodology}

This research was conducted using the fifteen $8^{\text {th }}$ grade Sciences TB most distributed in the country, according to PNLD / 2014 (see Table 1). The data analysis collected in the TBs was done using two analytical matrices proposed by Bernard et al. (2008). The matrix 1 (Chart 1) was used to identify the presence of indicators referring to male and female condoms, STIs and other related occurrences in texts and images arranged in the TB. While the matrix 2 (Chart 2) was used to identify the educational model of textual content used to talk about STIs and condom use in TBs. 
Table 1. Textbooks**.

\begin{tabular}{|c|c|c|c|c|c|c|}
\hline TB & Publisher & ISBN & Textbook title & \multicolumn{2}{|c|}{$\begin{array}{l}\text { Number and title } \\
\text { of the chapter }\end{array}$} & Pages \\
\hline A & Ática & $978-850815659-7$ & $\begin{array}{l}\text { Projeto Teláris - Ciências } \\
\text { Nosso Corpo }\end{array}$ & $\begin{array}{l}18 \text { - Doenças } \\
\text { Transmissíveis }\end{array}$ & Sexualmente & $246-256$ \\
\hline B & Moderna & 978-85-16-06885-1 & $\begin{array}{l}\text { Projeto Araribá - } \\
\text { Ciências }\end{array}$ & 2 - Período de & mudanças & $50-53,62-63$ \\
\hline C & Moderna & 978-85-16-08109-6 & $\begin{array}{l}\text { Ciências Naturais - } \\
\text { Aprendendo com o } \\
\text { cotidiano }\end{array}$ & $* *$ & & \\
\hline $\mathrm{D}$ & FTD & $978-85-322-8197-5$ & $\begin{array}{l}\text { Ciências novo pensar - } \\
\text { Corpo humano }\end{array}$ & $\begin{array}{l}8 \text { - Sexualidad } \\
\text { Reprodução }\end{array}$ & & 213-221 \\
\hline $\mathrm{E}$ & Ática & $978-850815667-2$ & $\begin{array}{l}\text { Ciências - o corpo } \\
\text { humano }\end{array}$ & $\begin{array}{l}7 \text { - Corpo } \\
\text { e mente: os } \\
\text { cuidados na } \\
\text { adolescência }\end{array}$ & $\begin{array}{l}5 \text { - O sistema } \\
\text { genital: } \\
\text { falando de } \\
\text { sexo }\end{array}$ & $72-82$ \\
\hline $\mathrm{F}$ & Saraiva & 978-85-02-16143-6 & Companhia das Ciências & $\begin{array}{l}19 \text { - Doenças } \\
\text { Sexualmente } \\
\text { Transmissíveis }\end{array}$ & $\mid \begin{array}{l}18-\text { Métodos } \\
\text { anticoncep- } \\
\text { cionais }\end{array}$ & $200-217$ \\
\hline G & Moderna & 978-85-16-07192-9 & Observatório de Ciências & $\begin{array}{l}14 \text { - Métodos } \\
\text { contraceptivos }\end{array}$ & s e DST & $204-216$ \\
\hline $\mathrm{H}$ & Saraiva & $978-85-02-17056-8$ & Jornadas.CIE - Ciências & $\begin{array}{l}13 \text { - Fecundaç } \\
\text { e parto }\end{array}$ & ão, gestação & 204-213 \\
\hline I & FTD & $978-85-322-8128-9$ & $\begin{array}{l}\text { Vontade de saber } \\
\text { Ciências }\end{array}$ & $\begin{array}{l}16 \text { - A prepro } \\
\text { humana: fecur } \\
\text { gestação }\end{array}$ & $\begin{array}{l}\text { dução } \\
\text { ndação, }\end{array}$ & $269-278$ \\
\hline $\mathrm{J}$ & IBEP & $978-85-342-3109-1$ & $\begin{array}{l}\text { O corpo humano: nossa } \\
\text { vida na Terra }\end{array}$ & 22 - Gestação & e parto & 232 \\
\hline K & SM & $978-85-7675-913-3$ & $\begin{array}{l}\text { Ciências - Para viver } \\
\text { juntos }\end{array}$ & $\begin{array}{l}9 \text { - Sexualidad } \\
\text { e genética }\end{array}$ & e, reprodução & $212-226$ \\
\hline $\mathrm{L}$ & $\mathrm{EB}$ & $978-85-10-05202-3$ & Perspectiva Ciências & 3 - Saúde e se & xualidade & $117-123$ \\
\hline M & Positivo & $978853854964-2$ & $\begin{array}{l}\text { Ciências para nosso } \\
\text { tempo }\end{array}$ & $\begin{array}{l}25 \text { - Métodos } \\
\text { contraceptivo }\end{array}$ & s e DST & $243-248$ \\
\hline $\mathrm{N}$ & Saraiva & $978-85-02-16151-1$ & Ciências Naturais & $* *$ & & \\
\hline $\mathrm{O}$ & Scipione & $978-852629184-3$ & Projeto Radix - Ciências & 7 - Reproduçã & o humana & $257-266$ \\
\hline
\end{tabular}

${ }^{* *}$ TB that did not approach the theme of this project.

Source: The authors. 
Chart 1. Analytical matrix 1: identification of male and female condoms and STIs, and other events on textbook's chapters.

\begin{tabular}{|c|c|c|c|}
\hline Conceptions & Indicators & $\begin{array}{c}\text { Images } \\
\mathrm{n}^{\mathrm{o}} \text { occurrences }\end{array}$ & $\begin{array}{c}\text { Text } \\
\text { Yes/No }\end{array}$ \\
\hline Male condom & $\begin{array}{l}\text { Male condom image type } \\
\text { Rolled condom } \\
\text { Unrolled condo } \\
\text { Penis in erection wih condom } \\
\text { Penis with condom penetrating vagina } \\
\text { Condom on a penis-shaped object } \\
\text { Other (specify) }\end{array}$ & $\begin{array}{l}\text { Photo } \\
\text { Schema/Drawing }\end{array}$ & \\
\hline Female condom & $\begin{array}{l}\text { Female condom image type } \\
\text { Rolled condom } \\
\text { Unrolled condo } \\
\text { Condom inside the vagina } \\
\text { Other (specify) }\end{array}$ & $\begin{array}{l}\text { Photo } \\
\text { Schema/Drawing }\end{array}$ & \\
\hline $\begin{array}{l}\text { Sexually Transmitted } \\
\text { Diseases/Infections } \\
\text { (STDs/STIs) }\end{array}$ & $\begin{array}{l}\text { Sexually Transmitted Diseases (STDs) } \\
\text { Sexually Transmitted Infections (STIs) } \\
\text { AIDS } \\
\text { HIV } \\
\text { Others STDs } \\
\text { Chlamyhdia } \\
\text { Genital Herpes (HSV) } \\
\text { Genital Warts (HPV) } \\
\text { Syphilis } \\
\text { Gonorrhoca } \\
\text { Chancroid } \\
\text { Viral hepatitis } \\
\text { Vaginitis } \\
\text { Others (specify which STI) }\end{array}$ & & \\
\hline
\end{tabular}

Source: Bernard et al. (2008, p. 190).

\section{Results and Discussion}

\section{Identification of male and female condoms on the TB}

The identification of images related to the male condom in the TB was used to quantify the TBs which contained: (a) the rolled condom (Figure 1A), (b) the unrolled condom (Figure 1B), (c) erect penis into the condom (Figure 1C), (d) the penis penetrating the vagina with a condom and (e) the condom on the penis mold. In the following descriptions (captions and 
Chart 2. Analytical matrix 2: matrix analytics to identify the educational style in textual content about STIs and condom using in the textbooks.

\begin{tabular}{|c|c|c|c|c|}
\hline $\begin{array}{l}\text { Educational } \\
\text { style }\end{array}$ & $\begin{array}{l}\text { Informative and } \\
\text { imperative/ } \\
\text { injunctive }\end{array}$ & $\begin{array}{c}\text { Informative and } \\
\text { imperative/ } \\
\text { indicative }\end{array}$ & $\begin{array}{l}\text { Informative and } \\
\text { participative }\end{array}$ & Only informative \\
\hline Problematic & $\begin{array}{l}\text { Absent or present, } \\
\text { but solutions are } \\
\text { imposed with no } \\
\text { argumentation }\end{array}$ & $\begin{array}{l}\text { Present, but the } \\
\text { argumentation } \\
\text { tends only to a } \\
\text { specific solution }\end{array}$ & $\begin{array}{l}\text { Present, or to be } \\
\text { discovered (by the } \\
\text { students). Open to } \\
\text { debate }\end{array}$ & Absent \\
\hline $\begin{array}{l}\text { Proposal for } \\
\text { action }\end{array}$ & Action imposed & $\begin{array}{l}\text { Strong suggestion } \\
\text { for the proposed } \\
\text { actions which are } \\
\text { also the only ones } \\
\text { justified }\end{array}$ & $\begin{array}{l}\text { Actions to be } \\
\text { constructed, or to } \\
\text { be chosen by the } \\
\text { students }\end{array}$ & None \\
\hline $\begin{array}{l}\text { Sentence } \\
\text { style and } \\
\text { structure }\end{array}$ & $\begin{array}{l}\text { 'You must do this'; } \\
\text { 'Do that'; 'Because } \\
\text { it is as it is'; 'Because } \\
\text { this is the way'; } \\
\text { 'Because science } \\
\text { shows it'; 'Because } \\
\text { religion says that' } \\
\text { e.g.: 'Condom is a } \\
\text { very thin rubber } \\
\text { case used by a } \\
\text { man, it must be put } \\
\text { on before sexual } \\
\text { intercourse and must } \\
\text { be used only once.' }\end{array}$ & $\begin{array}{l}\text { 'You can conclude } \\
\text { that'; 'It should } \\
\text { be conclude that'; } \\
\text { 'You should do } \\
\text { this'; 'Do that' } \\
\text { e.g.: 'Use more } \\
\text { and more it has } \\
\text { the advantage of } \\
\text { having a role in } \\
\text { both contraception } \\
\text { and prevention } \\
\text { of sexually } \\
\text { transmitted } \\
\text { diseases such as } \\
\text { AIDS.' }\end{array}$ & $\begin{array}{l}\text { Presenting several } \\
\text { points of view; } \\
\text { Several solutions } \\
\text { proposed; Askins } \\
\text { for students ideas, } \\
\text { suggestions } \\
\text { e.g.: Several different } \\
\text { contraceptive } \\
\text { practices are } \\
\text { cited with their } \\
\text { advantages and their } \\
\text { inconveniences. }\end{array}$ & $\begin{array}{l}\text { 'The data are'; } \\
\text { 'The facts are'; } \\
\text { 'The situation is'; } \\
\text { 'The interpretation } \\
\text { is'; 'The most } \\
\text { important thing to } \\
\text { know is' } \\
\text { e.g.: 'Many couples } \\
\text { wish to choose } \\
\text { the moment for } \\
\text { having a baby; } \\
\text { Birth control } \\
\text { is possible by } \\
\text { methods of } \\
\text { contraception.' }\end{array}$ \\
\hline
\end{tabular}

Source: Bernard et al. (2008, p. 189).

body text) TB is the acronym used for the textbook, followed by a letter corresponding to a particular book, according to Table 1.

Then, it was found out that from the fifteen analyzed TBs, $2(13.34 \%)$ did not approach the SE theme. Among the $13(86.66 \%)$ that treated the subject SE, graphics of more than one type of condom configuration were observed in most of the cases. Therefore, $9(60 \%)$ shown rolled condom images, $11(73.34 \%)$ had images of the erect penis into the condom and the other $2(13.33 \%)$ the unrolled condom. 
Figures 1A, 1B, 1C, 1D: male condoms. (1A) rolled condoms; (1B) unrolled condom; (1C) erect penis in the condom; (1D) procedure for condom use

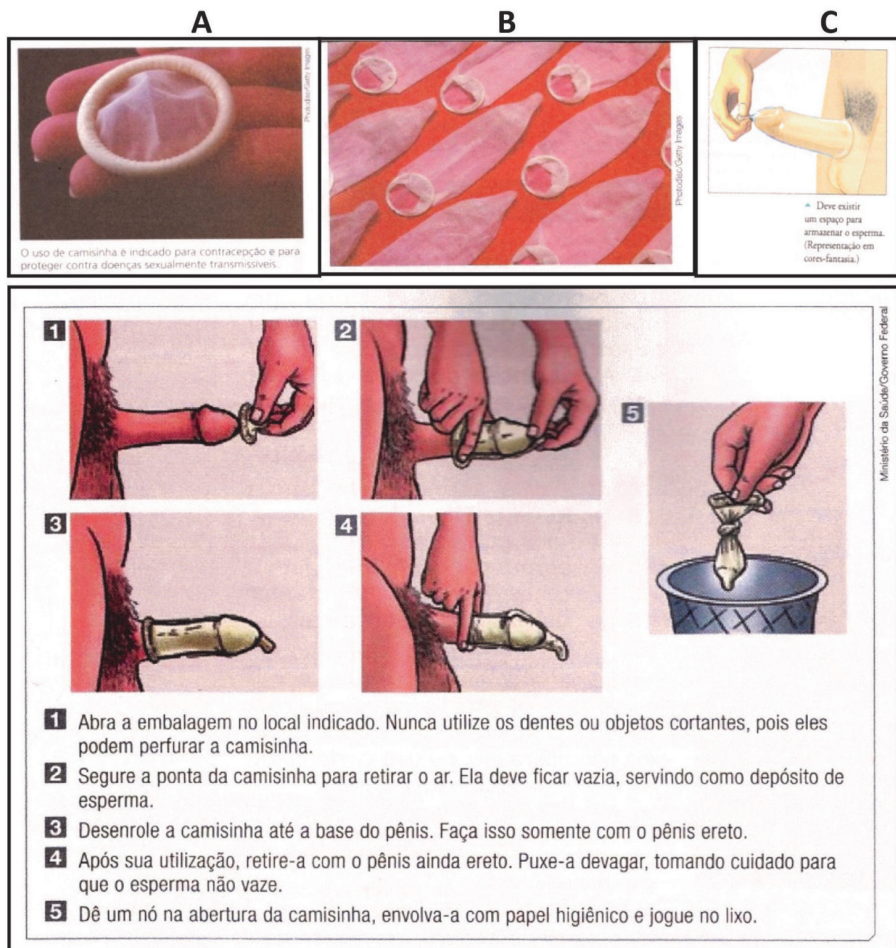

D

Source: TB D, p. 215; TB F, p. 203; TB I, p. 270 (see Table 1).

None of the analyzed TBs contained pictures of condoms on penis mold. We believe that the lack of pictures of erect penis into the condom could be compensated by images of penis mold with a condom. Images of the penis penetrating the vagina with condom were not found. By analyzing the TBs, it could be observed that in those which contained pictures of erect penis with a condom, the authors chose to inform the students through images, how to use the male condom (Figure 1).

The authors of the TBs who put images with procedures for condom use, followed a similar image pattern, they used illustrations with male body sections (Figure 1C). Like Macedo (2005, p. 134) said in her study, when the TB tries to highlight an organ of the human body, it eventually dismembers the bodies and presents it as something apart from the human body. Some TBs authors discreetly overcome the issue to illustrate the procedures of condom use in combination with the external genitals region (pubic hair and scrotum can be visualized), as seen in Figure 1D. This can be considered a small advance, since the character, with face, expression, "life", is absent at the time of condom use, a situation of singular importance. 
Regarding the texts that had images related to condom use, it can be seen that some are composed of alerts that can prevent future problems, as seen in Figure 1D, where the first instruction given is not to use sharp objects, not to perforate the condom. Zambenedetti (2012) points out that during his research he observed demonstrations of incorrect placement of the condom on the penis prosthesis, because of the lack of information. Moreover, this author heard reports of the use of sharp objects such as scissors and tooth for opening the condom package. While displaying images, not all authors took into consideration the points mentioned above approaching the use of condoms, because in some TB (TB F, p. 203 and TB E, p. 75), some authors did not bother with the procedure nor on giving information such as - do not use sharp objects to open the condom.

In the analysis about the female condoms in TB the objective was to quantify the number of TB containing images of rolled female condom, unrolled female condom and female condom into the vagina. From this analysis it can be seen that none of TB analyzed contained images of rolled female condoms. However, $9(60 \%)$ authors chose to use the image of the female condom unrolled (Figure $2 \mathrm{~A})$, and $6(40 \%)$ had a female condom into the vagina (Figure $2 \mathrm{~B}$ ).

As occurred with some images of male condoms in TBs, some authors also chose to have images of the female condom into the vagina, aiming to illustrate the handling of the female condom, as seen in (Figure 2C).

Figures 2A, 2B, 2C - Female condoms

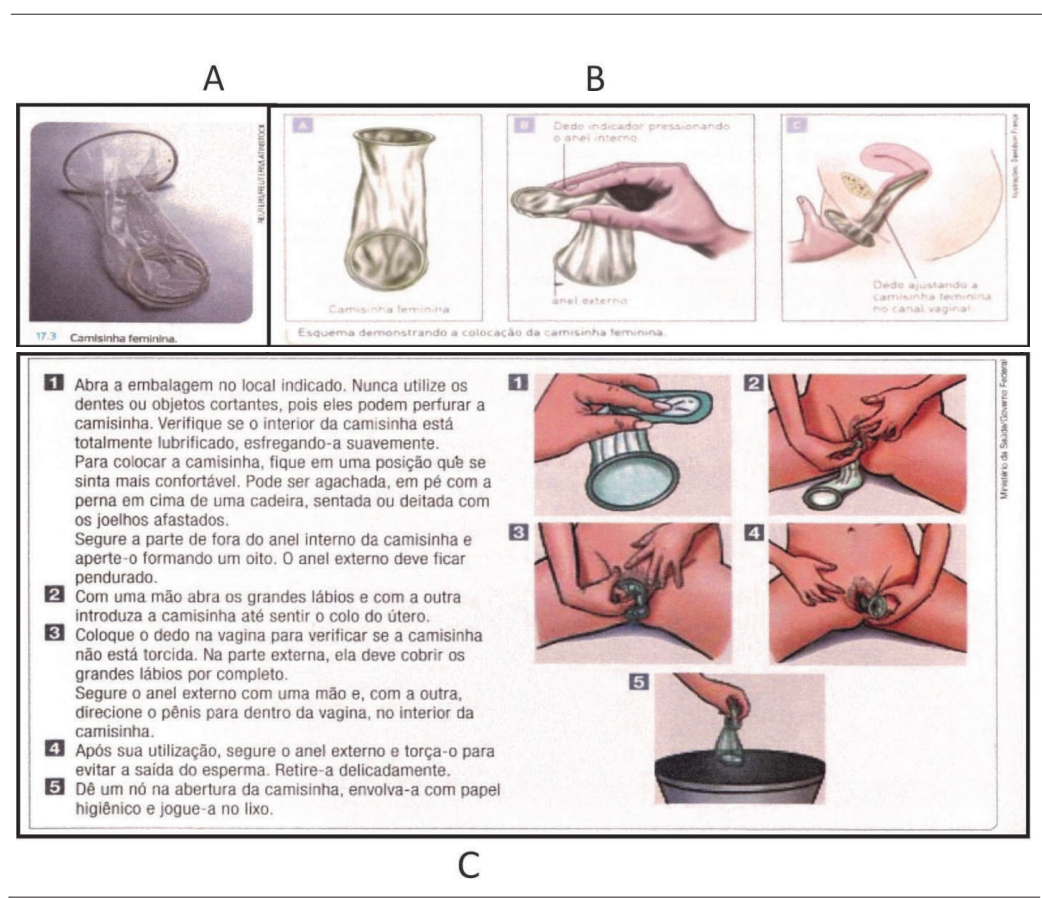

Source: TB A, p. 239; TB L, p. 122; TB I, p. 270 (see Table 1). 
Similar to what has been observed on the male condom images, while exposing pictures of female condoms the authors of TBs chose graphics of female bodies sectioned to illustrate the handling of the condom (Figure 2C). Still, the authors of TB in Figure 10 did not bother to have on the TB much information that could clarify or avoid the uninformed use of female condoms.

The TB image analysis, referring to male and female condoms, has allowed us to say that there are no illustrations of the sexual act, through representations such as: condoms penis penetrating the vagina or penis penetrating the vagina with a female condom. There are no illustrations of safe sex (with condom) between gay partners either.

The absence of the representations mentioned above does not help the understanding about the use of condoms. Besides, Bernard et al. (2008) argues that the lack of pictures of erect penis and the penis in the vagina indicates a taboo regarding sex, in other words, a fear of exposing, even in an illustrative manner, the sexual act in a TB. In addition to the issues highlighted above, we propose other explanations for such analysis results.

Initially, the Educational system in the perspective of Chevallard (1998) could consider that the visualization of a sexual intercourse, even "schematic" could encourage early sexual intercourse among young people, as confirmed by the study of Irala, Gómara Urdiain and López de Burgo (2008). These authors argue that teenagers could be influenced to initiate sexual activity prematurely, given the apparent safety transposed in the TBs, because of the condoms use. Louro (2000) says that patterns of social conduct indicate that the beginning of sexual activity should be postponed until adulthood. Maybe, this is the reason why the TB authors hesitate to expose pictures showing the sexual act.

Another important point is the TB authors' commitment with heteronormativity. The absence of images in the TB showing sexual act between partners of the same sex can be an implicit signal that the relationship between heterosexual partners is the only seen as normal or natural. Then, according to it, relationships that do not fit this pattern would not be relevant in SE, therefore should not be discussed (LOURO, 2000; SNYDER; BROADWAY, 2004; TEMPLE 2005). Temple (2005) argues that the absence of discussions about homosexuality in the TB, conveys a view that there are no homosexuals in the classroom, or even in the world. Denying and ignoring homosexuality makes opportunities for teenagers or adults to admit their sexuality, nonexistent in the school system (LOURO, 2000).

While reading the TB, the students talk with themselves, (SNYDER; BROADWAY, 2004) then, they could see the different sexual orientations contemplated in TB, an aspect that does not encourage the students to be homosexual, transgender, bisexual, etc., but it could contribute to the development of some aspects such as criticality, tolerance and respect, among others. From the moment that the young person has access to several types of information, they will not be easily persuaded, on the contrary, they will have enough basis to judge if that information is consistent with their values, with what they believe or not.

Discussions about sexual intercourse and condom use in the TB could be enriched by other issues that teenagers are used to see around them. Marston and King (2006) highlighted some issues that are directly related to condom use. We argue that some of these should be contained in the discussions prompted by TB. We are going to describe four themes with the objective of to improve these instructional resources. 
1. Young people subjectively consider sexual risk-sharing partners based on the appearance, if they are "clean" or not. Knowing the sexual partner for a long time, knowing their social life, or how easy it was to have intercourse with this partner, is not an indicator of the presence/absence of an STI, but the condom use by young people is often associated with these factors.

2. Condom use may be related to lack of confidence, in other words, proposing condom use during sexual intercourse may suggest that one partner is a carrier of some STIs.

3. Sexual partners influence generally in sexual behavior and the condom use can be conditioned to situations where one of the partners asks to have sexual intercourse without a condom, a recurring situation of gender violence, for example.

4. Gender stereotypes determine sexual behavior, such as men need to be sexually active and women are embarrassed to carry condoms.

\section{Sexually transmitted infections in TB and its relationship with the incidence in Brazil}

The main purpose of the IST analysis in TB was to know whether the IST approached in these ones are related to the number of occurrences of each disease in Brazil. The analysis of the TB allowed knowing that most authors when dealing with STIs in TB, emphasized those with the highest number of cases in Brazil. From the fifteen analyzed TBs, 13 (80\%) chose to approach AIDS and gonorrhea, 11 (66.67\%) Genital Herpes and Syphilis, 11 (66.67\%) HPV, 8 (53.33\%) Hepatitis B and 7 (46.67\%) Candidiasis. On the other hand, despite the large number of Chlamydia cases in Brazil, 1,967,200 cases in 2012, only 6 TB (40\%) approached Chlamydia. From the fifteen analyzed TB, 13 approached, in a short way, AIDS. It emphasizes that two of these TB did not approached the SE, so all the TB that have committed to treat the SE in its pages, and approached AIDS.

The objective was also to analyze, using the analytical matrix 1, which authors have used the new STI nomenclature replacing STD on TB. It was found that in none of the analyzed TB the authors used the new nomenclature. According to Magalhães (2006) the World Health Organization (WHO) adopted in 1999 the use of STI abbreviation instead of STD. This is because a person may have an infection and not develop the disease, such as AIDS, the individual may have HIV and do not develop the syndrome.

Looking at the images of each IST on the TB, it was found that in only $8(53.34 \%)$ from the fifteen TB analyzed the authors inserted images related to STI. However, $85.71 \%$ were graphics images, as shown in Figure 3 (A, C and D). Just one image (14.29\%) was of a patient with signs of disease (Figure 3B), showing wounds caused by syphilis and other 2 pictures $(13.34 \%)$ were representations of syphilis and gonorrhea (Figure 3C and 3D).

Images of patients with signs of the mentioned diseases on TB could be better, it could exemplify the consequences of sexual intercourse without a condom. The images shows a directly idea than words, and may contextualize what was said, transcending the textual information (MARTINS; GOUVEA; PICCININI, 2005). Some authors chose the virus images (Figure $3 \mathrm{~A}$ ) an aspect that contributes just a little to a change of mind by the reader, since that no impact is being caused. 
Figures 3A, 3B, 3C, 3D. (A) HIV Virus (B) Wounds caused by syphilis (C) Secretion caused by gonorrhea (D) Hard lesions caused by syphilis

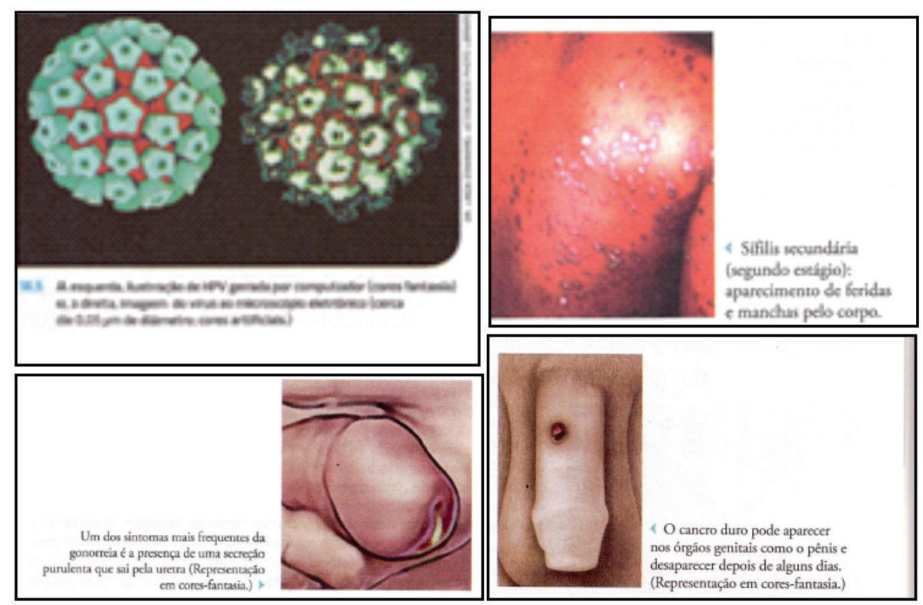

Source: Images: TB A, p. 249; TB F, p. 213 (see Table 1).

\section{Educational style in textual content on STI and the use of condom on TB}

This session is the result of analysis made using the analytical matrix 2, focusing on the identification of educational style in textual content on STI and Condom use on TB.

The writing of an author can reveal his opinion on the topic that is being worked, and may also be intended to manipulate the reader's opinion; in the case of TB and the school community. It is known that to write something is almost impossible not to transmit values and opinions, the difference is that some texts may impose certain behaviors, attitudes, practices and not only discuss or contextualizes them.

Based on this, the educational style of the textual content on TB was classified into four types of writing, according to Bernard et al. (2008). In Informative and Imperative/Indicative, the author orders how the society should behave. Following a similar pattern, there is the Informative and Persuasive/Indicative writing which does not impose actions but makes a strong suggestion to some attitudes without justifying why to adopt them. The Participative writing informs the reader, including the subject on the discussion, allowing it to make its own choices. Finally, the Informative and Descriptive writing reports and describes actions, but does not try to include the reader in a discussion that allows them ask questions about what is being read.

The analysis showed that $2(13.33 \%)$ from the 15 analyzed TB used Informative and Participative educational style. In such cases, the authors included students in discussions, using elaborations as: (1) "From the 1980s there was an increase in condom use due to the increase in the number of AIDS cases. However, in recent years, the use of condoms among young people has declined. Think about the consequences that this may cause to public health in the future". (TB I, p. 279, our translation. See Table 1). 
The Informative and Participative educational style clearly tries to insert the student in a discussion, using group activities and even image interpretation. According to Ferreira et al. (2012, p. 476, our translation), the Informative and Participative style could greatly help in the student's learning process, "because it could encourage the development of skills in students regarding behaviors that involve health risks".

Talking about the Informative and descriptive educational style, $9(60 \%)$ of the fifteen TB analyzed in this category, used only the exposure of concepts, for example, "The diaphragm is a latex membrane circumvented by a ring that fits around the uterine colon. Placed before the sexual intercourse, it prevents the passage of semen into the uterus preventing the conception" (TB J, p. 232, our translation). Different from Informative and Participative writing, the Informative and Descriptive educational style does not provide the discussion of thematics that are not in the TB.

From the fifteen analyzed TB, $2(13.33 \%)$ used the Informative and Persuasive/Indicative Educational Style. In these the author's opinion could clearly be seen on the ES, through issues that are clearly influential, such as: (1) "Abstaining from sex or having intercourse with an uninfected and faithful partner are also forms of effective protection against sexually transmitted diseases" (TB A, p. 239, our translation), (2) "Among the factors that contribute to the emergence of sexually transmitted diseases, it can be cited to greater freedom of manners, promiscuity and mostly ignorance" (LD D, p. 218 our translation). Sexual intercourse with an uninfected and faithful partner is a form of protection against STIs, however, when a TB brings this kind of position the author is not impartial anymore, the authors are taking position when they should be impartial regarding the theme.

The authors of the TB named A, B, F, G, H, I, J, K, approached condom use and STI and also issues that were strongly related to $\mathrm{SE}$, as the use of emergency contraceptive pills , biological sex, gender, sexual orientation, homophobia, pedophilia, breast cancer, andropause, menopause. As discussion strategy one of these authors, despite using the informative and descriptive style to approach STI/AIDS and condoms, they used a participative educational style to talk about the morning-after pill,

As its name says, the emergency contraception should be used only in exceptional cases and should not be the rule. An example of its use is when the condom breaks during sex. In this case, the emergency contraception is indicated. This contraception is also known as the morning-after pill, as it must be used within 72 hours after sex. The hormones of this pill prevent pregnancy by inhibiting ovulation, fertilization and blastocyst implantation. Some people are against the use of emergency contraception saying it is abortive. What is your opinion about this? On what do you base your conclusions on? (TB M, p. 247, our translation).

Sexual Education (SE) is a broad theme, it is not just about condoms and STI. When the TB authors prompt a discussion, other issues may surface. These subjects include, besides the sanitary doctor dimension, SE biologist, elements on a broader discussion about sexuality, such as gender, sexual orientation and homophobia. Bring up this kind of discussion contributes to the formation of more prepared individuals for taking individual and collective decisions. 


\section{Conclusion}

The results showed that there is a huge difference between what is presented on the TB and what students want or need to have access to start thinking, learning and making decisions.

Considering the student's fascination on SE thematic, and its interface between education and health opportunities, science and society, it is important to carry out detailed analysis of this theme in TB contemplating, among other things, iconographic elements and textual content related to STI/AIDS and condoms.

The analysis made in this study led to some considerations about the images linked in these materials. Many authors have avoided images that represented the sexual intercourse, heterosexual or homosexual. For example, none of the TB analyzed contained penis pictures with condom penetrating in the vagina.

It was found that the TB authors considered the STIs most predominant in Brazil and in the world, as observed in the case of AIDS, which was cited in all TB analyzed. However, none of the TB analyzed used the STI nomenclature, replacing the STD, and this recommendation was made by WHO 15 years ago.

Concerning the textual educational style used by the authors analyzed in the 15 TBs, some limitations must be reinforced. Although a large number of TBs with Persuasive/Indicative Style was not found, it is suggested that some authors must to take care in writing their texts in a way it does not become clearly partial regarding some social practices. Only two TBs were classified as informative and participative. This style allows the discussion, display of ideas about the theme that can be inserted in the TBs and that probably they have already been discussed in their social/family life.

Finally, from the analysis made it is concluded that in the 15 most distributed TB in Brazil, interactions between KVP variables, scientific knowledge, values and practices, respectively, had a great influence on what was exposed, making necessary the future discussion about inserting many issues related to STI/AIDS and condoms in the TBs.

\section{References}

ARAUJO, E. S. N. N. et al. Concepções criacionistas e evolucionistas de professores em formação e em exercício. In: ENCONTRO NACIONAL DE PESQUISA EM EDUCAÇÃO EM CIÊNCIAS, 7., 2009, Florianópolis. Atas... Florianópolis: ABRAPEC, 2009. Retrieved from: <http://posgrad.fae.ufmg.br/posgrad/viienpec/pdfs/1186.pdf>. Accessed 25 Sep. 2014.

BERGER, D. et al. Sex education: teachers' and futures teachers' conceptions and social representations: what relevance for teachers' training? In: IOSTE SYMPOSIUM ON THE USE OF SCIENCE AND TECHNOLOGY EDUCATION FOR PEACE AND SUSTAINABLE DEVELOPMENT, 13., 2008, Izmir, Turkey. Proceedings... Ankara: Palme Publications \& Bookshops, [2008]. p. 1-7. Retrieved from: <http:// repositorium. sdum.uminho.pt/bitstream/1822/8932/1/IOSTE_SexEduc.pdf>. Accessed 20 Feb. 2014. 
BERNARD, S. et al. Sexually transmitted infections and the use of condoms in biology textbooks: a comparative analysis across sixteen countries. Science Education International, Izmir, v. 19, n. 2, p. 185-208, 2008.

BRASIL. Ministério da Educação. Edital de convocação para o processo de inscrição e avaliação de coleções didáticas para o Programa Nacional do Livro Didático: PNLD 2014. Brasilia, 2014a. Retrieved from: < http://www.fnde.gov.br/programas/livro-didatico/ livro-didatico-editais $>$. Accessed 10 Dec. 2015.

BRASIL. Ministério da Saúde. Boletim epidemiológico: HIV e AIDS. Brasília, 2013.

. Departamento de DST, AIDS e hepatites virais: portal sobre Aids, doenças sexualmente transmissíveis e hepatites virais. Brasília, 2014b.

CARVALHO, G. S. A transposição didática e o ensino da biologia. In: CALDEIRA, A. M. A. C.; ARAÚJO, E. S. N. N. (Org.). Introdução à didática da biologia. São Paulo: Escrituras, 2009. p. 34-57.

CARAVITA, S. et al. Construction and validation of textbook analysis grids for ecology and environmental education. Science Education International, Izmir, v. 19, n. 2, p. 97-116, 2008. Retrieved from: <http://files.eric.ed.gov/fulltext/EJ890627.pdf>. Accessed 23 May 2016.

CHEVALLARD, Y. La transposición didáctica: del saber sabio al saber enseñado. 3. ed. Buenos Aires: Aique, 1998.

CLÉMENT, P. Didactic transposition and KVP model: conceptions as interactions between scientific knowledge, values and social practices. In: SUMMER School 2006: programme \& synopses. Braga: Universidade do Minho: Instituto de Estudos da Criança, 2006. p. 9-18. Retrieved from: < https://www.esera.org/media/summerschool/esera2006/BookPDF_ summer_school_2006.pdf>. Accessed 23 May 2016.

DE IRALA, J.; GÓMARA URDIAIN, I.; LÓPEZ DE BURGO, C. Analysis of content about sexuality and human reproduction in school textbooks in Spain. Public Health, London, v. 122, n. 10, p. 1093-1103, 2008. Retrieved from: <http://dadun.unav.edu/ bitstream/10171/19612/1/school_textbooks_of_Spain_pp.pdf > . Accessed 23 May 2016.

FERREIRA C. et al. Como as infecções sexualmente transmissíveis são apresentadas em manuais escolares de 16 países e que formas de prevenção são facultadas. In:

ALBUQUERQUE, C. M. S. (Org.). Comportamentos de saúde infanto-juvenis: realidades e perspectivas. Viseu: Escola Superior de Saúde, 2012. p. 465-478. Retrieved from: $<$ https:/ / www.dgs.pt/documentos-e-publicacoes/comportamentos-de-saude-infantojuvenis-realidades-e-perspetivas-jpg.aspx>. Accessed 23 May 2016.

GUIMARÃES, M. D. M. et al. A Teoria Gaia é um conteúdo legítimo no ensino médio de Ciências? Pesquisa em Educação Ambiental, Ribeirão Preto, v. 3, n. 1, p. 73-104, 2008.

Retrieved from: <http://www.revistas.usp.br/pea/article/view/30040/31927>. Accessed 23 May 2016. 
LOURO, G. L. O corpo educado: pedagogias da sexualidade. 2. ed. Belo Horizonte: Autêntica, 2000.

MACEDO, E. Esse corpo das ciências é o meu? In: AMORIM, A. C. et al. (Org). Ensino de biologia: conhecimentos e valores em disputa. Niterói: Eduff, 2005. p. 131-140.

MAGALHÃES, R. S. M. Promoção da saúde em instituições de apoio a prostitutos/as de rua: perspectivas de técnicos e utentes. 2006. Tese (Mestrado em Promoção da Saúde e do Meio Ambiente) - Instituto de Estudos da Criança, Universidade do Minho, Braga, 2006. Retrieved from: <http://hdl.handle.net/1822/6212>. Accessed 23 May 2016.

MARSTON, C.; KING, E. Factors that shape young people's sexual behaviour: a systematic review. The Lancet, London, v. 368, n. 9547, p. 1581-1586, 2006.

MARTINS, I.; GOUVEA, G.; PICCININI, C. Aprendendo com imagens. Ciência e Cultura, São Paulo, v. 57, n. 4, p. 38-40, 2005. Retrieved from: < http://cienciaecultura.bvs. br/pdf/cic/v57n4/a21v57n4.pdf >. Accessed 23 May 2016.

NUNES, P. S. et al. Educação sexual: as relações entre conhecimentos, valores e práticas sociais de prevenção da disseminação do vírus HIV. In: ENCONTRO NACIONAL DE PESQUISA EM EDUCAÇÃO EM CIÊNCIAS, 8., 2011, Campinas. Atas... Retrieved from: <http:/ / www.nutes.ufrj.br/abrapec/viiienpec/resumos/R0867-1.pdf>. Accessed 28 March 2014.

SNYDER, V. L.; BROADWAY, F. S. Queering high school biology textbooks. Journal of Research in Science Teaching, Hoboken, v. 41, n. 6, p. 617-636, 2004.

TEMPLE, J. R. "People who are different from you": heterosexism in Quebec high school textbooks. Canadian Journal of Education, Ottawa, v. 28, n. 3, p. 271-294, 2005.

WORLD HEALTH ORGANIZATION. HIV/AIDS. [S.l.: s.n.], 2014. (Fact sheet, 360). Retrieved from: <http://www.who.int/mediacentre/factsheets/fs360/en/>. Accessed 9 March 2014.

ZAMBENEDETTI, G. Sala de espera como estratégia de educação em saúde no campo da atenção às doenças sexualmente transmissíveis. Saúde e Sociedade, São Paulo, v. 21, n. 4, p. 1075-1086, 2012. Retrieved from: <http://dx.doi.org/10.1590/S0104$12902012000400024>$. Accessed 10 June 2014.

Artigo recebido em 30/03/2015. Aceito em 28/11/2015.

Endereço para contato: Universidade Federal do Recôncavo da Bahia, Centro de Ciências Agrárias, Ambientais e Biológicas, Rua Rui Barbosa 710, Centro, CEP 44380-000, Cruz das Almas, BA, Brasil. 